\title{
Assessing the contribution of the capital markets on the economic growth of Botswana
}

\author{
Ishmael Radikoko
}

Alice 0. Gaolatlhe

Mashoko T. Dzimiri

Mogotsinyana Mapharing

\begin{abstract}
This paper evaluates the contribution of capital markets on the economic growth of Botswana. It focuses on the bond markets and stock markets using the Botswana Bond Index and the Domestic Companies Index as proxies respectively, and Gross Domestic Product as a measure of economic growth. A 6 year quarterly time series data from 2012 to 2017 was used in the analysis. Multiple regressions model was employed followed by cointegration test to establish the significance and long-run relationship respectively between capital markets and economic growth. Vector Error Correction Model is also employed to check for short term dependencies in the data series used. The findings from this research suggest that capital markets in Botswana do not contribute to economic growth in the short run. However, in the long run capital markets do contribute to economic growth through further capital markets development. The implications are that in the short run government and policy makers should devise appropriate policies that will improve the development of capital markets as thus have a potential to foster economic growth in the long run.
\end{abstract}

Keywords: capital markets, economic growth, regression analysis, cointegration test, Vector Error Correction Model, Botswana

\section{INTRODUCTION}

Capital markets and their role in enhancing the economic growth of a country has generally been under-examined especially in less developed markets. Conversely, other financial institutions such as banks and their role in economic development have been examined extensively as they are considered more instrumental in accelerating economic growth (Phadke, 2015).Nonetheless, the role of capital markets in promoting economic growth has been documented in literature, especially in developed nations. The role can be understood from the point of view of fostering capital in the economy through savings mobilization, easing risk management, promoting technological transfer and reducing transaction costs (Schumpeter, 1911). Similarly, Arestis, Demetriades, and Luintel (2001) carried out a study in five developed countries of Germany, United States of America, United Kingdom, Japan and France from 1973 to 1998 on the role of stock markets on economic growth and their findings demonstrated that while stock markets may be able to contribute to long term economic growth, their impact was small as compared to the banking system. In particular, their findings revealed that the magnitude of banking development was seven times higher than the stock market development on real GDP, highlighting that the impact of banking system was stronger than that of the stock market.

In spite of the above findings, the increasing importance of stock markets around the world has opened a new avenue of research into the relationship between financial development and 
economic development (Arestis,Demitriates and Luintel, 2001). Though stock markets encourage specialization as well as acquisition and dissemination of information (Diamond, 1984; Greenwood \& Jovanovich, 1990) and may reduce the cost of mobilizing savings and thereby facilitating investment, the stock market can have a negative impact on economic growth due to its price volatility. Even though the results are a bit ambiguous, most studies have alluded to the positive role played by stock markets in fostering economic growth. Nonetheless, such positive role has been overlooked in developing countries due to their relatively smaller capital markets (Bulere, 2015). Levine (2005) postulates that capital markets influence economic growth through two channels, namely capital accumulation and technological innovation. With these factors it creates a developed financial system that reduces the external financing constraints, thus promoting a long-term economic growth. Nevertheless academic studies over the years have ignored capital markets or treated them as secondary in their contribution to economic growth (Goldsmith, 1969).

In Botswana, capital markets are facilitated by the Botswana Stock Exchange (BSE) formally known as the Botswana Share Market. It was established in 1989 and given the responsibility to operate and regulate the equities and fixed income securities market. As a way of reinforcing regulation of capital markets, the Non-Bank Financial Institutions and Regulatory Authority (NBFIRA) Act 2006 established NBFIRA whose mandate was among others, to regulate the BSE. In December 2015, a new Act called the BSE Transition Act was launched making a way for the origination of the demutualization of the BSE. The BSE has recently been demutualized and the Botswana Stock Exchange Limited (BSEL) was formed in 2018. Products that are currently being listed on the BSE are equities, corporate bonds, government bonds, exchangetraded funds, index funds and commercial papers and products that are under development are the global depository receipts and real estate investments trusts (Botswana Stock Exchange, 2018).The BSE continues to play a pivotal role in the Botswana financial system especially the capital markets as an avenue in which, government, quasi-government and the private sector can raise debt and equity capital (Botswana Stock Exchange, 2018). To date, the BSE is one of Africa's best performing stock exchanges averaging $24 \%$ in aggregate return in the past decade and the third largest stock exchange based on market capitalization in Southern Africa (Botswana Stock Exchange, 2017). Therefore the contribution made by BSE to the economy of Botswana is worth unraveling.

It has already been established that capital markets do influence economic growth (Levine \& Zervos, 1996; Haiss \& Hristoforova, 2003). From an African context, Everlyne, Esman, Roseline (2014) using annual data from a panel of 36 countries, of which 18 have stock markets in Africa over the period 1980-2010 found out among others that: (i) countries with stock markets tend to grow faster compared to countries without stock markets, (ii) countries which are relatively developed and have stock markets tend to grow less faster compared to small countries with stock markets, and (iii) Stock market development has a positive effect on economic growth in the African region. Hence, the outcome of this study cements the central role that stock markets play in promoting economic performance.

Although literature adequately suggest that capital markets are crucial for economic growth, their role in fostering economic growth has not been extensively studied in the context of Botswana. Moreover, the few available studies were carried out at least a decade ago, and with huge developments that has taken place in the Botswana's capital market in the last decade the findings of these earlier studies, could be irrelevant today. Among the few studies carried out in Botswana, Akinboade (1998) postulates that economic and financial development appear to complement each other. It was found out in their study that increasing per capita income can encourage the development of financial services in the country which can also augment further 
economic development through the provision of more services. However, this was carried out over the 1972-95 period, the earliest and the latest times for which financial data was available. Furthermore, most studies have mainly been focused on stock markets and banks and their relation with economic growth and less attention has been paid to the bond market and its impact on economic growth. Kapingura and Makheta-Khosi (2014) asserts that this could be due to the fact that the bond market is still developing in most emerging markets and their contribution to financial markets is still small. Additionally, Fink, Haiss and Hristoforova (2003) examined the causality between the bond market and economic growth in 10 countries and obtained mixed results. Thus, the findings on bond market's impact on economic growth are limited and inconclusive. Hence, this study aims to evaluate the contribution that capital markets (including both stock and bond markets) have on the economic growth of Botswana. In particular, we examine;

1. The contribution of stock market to the economy of Botswana

2. The contribution of the bond market to the economy of Botswana.

3. The long run relationship between capital markets and economic growth of Botswana

Based on literature review, the following hypothesis is formulated;

H1: Stock market contributes positively to the growth of the economy of Botswana

H2: Bond market contributes positively to the growth of the economy of Botswana.

H3: There is a long-run relationship between capital markets and economic growth.

The results of this study will assist in informing policy makers on the role capital markets play in fostering economic growth in Botswana and therefore guide them in formulating appropriate policies that will improve capital markets in Botswana. Furthermore, the study will contribute to the limited literature in developing countries such as Botswana.

The rest of the paper is arranged as follows; next we look at the literature review followed by data analysis, findings and discussion and we end with concluding remarks.

\section{Theoretical Review}

\section{LITERATURE REVIEW}

Schumpeter's Theory of Economic Development as cited by Elliott (1985) states that for economic development to happen financial innovation is vital which is the putting in practice of new ideas to create new money for entrepreneurs. Entrepreneurs will be individuals with the desire to create new things in order to attain their objectives. Economic development includes social and cultural changes that occur in the development process and not just economic growth alone (Robinson, 1972). Therefore this theory asserts that for economic growth to happen there has to be a vibrant capital market, whose players implement new ideas for the creation of new money in order for entrepreneurs to fulfill their objectives.

According to the Endogenous growth model, a developed financial system (including capital markets) is key to economic growth of a nation. The financial system is there to evaluate and choose most promising new innovative projects of entrepreneurs and provide them with funding (King \& Levine, 1993). The theory further states that financial system enables investors to diversify their risk through investing in new innovative promising projects and reveals their potential return as compared to existing projects (King \& Levine, 1993). King \& Levine (1993) according to their Endogenous growth model conclude that developed financial systems increases the chances of successful innovation and thereby spurring economic growth. 


\section{Empirical Review}

There are several previous empirical studies that have been carried out on the impact of capital markets to economic growth both in developing and developed countries and, this section will focus on reviewing those studies.

Kaserer \& Rapp (2014) examined the role of capital markets in Europe and found that increased capital market size had a positive relationship with economic growth. In particular, the equity market had positive impact to economic growth as compared to the debt market. Equity market's positive impact is due to availability of long-term funds for risky investments and improved corporate governance. Marques, Fuinhas \& Marques, (2013) explored the association between the stock market development and economic growth for Portugal during the period 1993 - 2011. Using the Granger causality test it was established that there was a bidirectional, positive causal relationship between stock market development and economic growth. It was also established that the banking system was a beneficiary of the economic growth. Coşkun, Seven, Ertuğrul \& Ulussever (2017) studied the relationships between development level of capital market and economic growth using monthly data from Turkey over the period of January 2006 and June 2016. Their study results revealed that there was unidirectional causality running from capital market development to GDP, and long run cointegration relationship between capital market development and economic growth. The government bond market development was negatively but the general capital market development was positively associated with economic growth. Koirala (2011) investigated the contribution of capital market development to economic development in the United Kingdom over a nine year period from 2001 to 2009. The market development was measured using market capitalization from London Stock Exchange (LSE) and Gross Domestic Product for economic development. The study used correlation and multiple regression analysis to determine the impact of capital market development. The findings show that there was positive and significant correlation between market capitalization and Gross Domestic Product. The regression results also show a positive and significant relationship between capital market development and economic growth. The study by Njemcevic (2016) aimed to establish the relationship of capital market activities on economic growth in South East Europe (SEE) region over ten year period, 2003 - 2012. The study used fourteen countries from SEE region and capital market liquidity and capitalization were used as market indicators whilst GDP per capita was for economic growth. Capital market liquidity had a positive and insignificant relationship with economic growth whilst market capitalization had a positive and significant relationship with economic growth. A study to establish the relationship between stock market development and economic growth in Romania, using data over the period 1995 - 2010 and Granger Causality test by Carp (2012), revealed that the stock market indicators, market capitalization and stock value traded had no impact on economic growth.

Nordin, S., \& Nordin, N. (2016) analysed the influence of stock market and bond market on the Malaysian economy using Johansen-Juselius co-integration test, the vector error correction model, Granger causality and variance decomposition. The study used the GDP per capita as proxy for economic growth, debt market was represented by both public and private debt and market capitalization of shares listed on Bursa Malaysia was used as equity proxy. Annual data for the period of 1981 to 2014 was used. The study found a co-integrating relationship between real growth domestic product per capita, stock market and debt market. The stock and debt market had positive and significant long-run influence on the economy. The stock market was found to exert uni-directional causality on the economy and had more influence as compared to debt market. Pradhan, Arvin \& Bahmani (2015) investigated the relationship between economic growth, inflation and stock market development using 34 OECD countries over the period 1960 - 2012. The study revealed that there was a long-run equilibrium 
relationship among all three variables and a unidirectional causality from both economic growth and stock market development to inflation in both the short run as well as the long run. Pan \& Mishra (2018) explored the relationship of the stock market and economic growth in China using unit root test and Autoregressive distributed lag (ARDL). The study found an insignificant long-run negative relationship between the stock market, the real economy and no relationship at all in the short-run between stock market and the real economy. Nuhiu \& Hoti (2011) carried out a study of the effects of capital markets development on economic growth of Western Balkan countries. The Western Balkan countries considered for the study were Albania, Croatia, Macedonia, Serbia, Montenegro and Bosnia which were developing nations. The study revealed that the capital market developments in Western Balkan countries have not had a positive impact to economic growth due to small size of the capital markets, low number of market participants, limited market information and high presence of the informal economy. Cooray (2010) carried out a study to determine the effects of stock market on economic growth for 35 developing countries over the period 1992 - 2003. The findings revealed that stock market proxies being market capitalization, market liquidity and turnover ratio had positive and highly significant association with economic growth.

Using a panel of 36 countries in Africa of which 18 countries had stock markets and the othe 18 had not, Ngare, Nyamongo \& Misati (2014) investigated the role of stock market on economic growth. The results indicated that stock market development had a positive effect on economic growth and countries with stock markets had a faster economic growth as compared those without. Enekwe, Eziedo \& Agu (2016) investigated the effect of stock market developments on economic growth in Nigeria over a 30 year period from 1981 to 2012. GDP was used as proxy for economic growth and market capitalization, total number of listed companies and total value of traded securities as stock market indicators. Descriptive statistics, Pearson correlation and multiple regressions were used to analyze the data. The results revealed that market capitalization had a positive and significant relationship with GDP. However, total number of listed companies and total value of traded securities both had negative and insignificant relationship with GDP. Yadirichukwu \& Chigbu (2014) in their study of the relationship between the stock market and economic growth in Nigeria covering the period $1985-2012$ using regression analysis revealed mixed results for the stock market indicators that were used. A long run inverse relationship existed between GDP and market capitalization whilst new issues and GDP had a positive long run relationship. The total listings and value of transactions in stock market both had an inverse relationship with GDP. A study in Ghana to establish the relationship between capital market development and economic growth using multiple linear regression based on quarterly data from 1991 to 2014 revealed a positive bidirectional relationship between capital market development and economic growth (AcquahSam \& 2014). However, a high impact relationship was noticed from the stock market development to economic growth. An empirical research on the impact of capital markets on economic growth in South Africa over the period 1971 - 2012 by Khetsi \& Mongale (2015) using Johansen co-integration test, VECM test and Granger causality test revealed a positive relationship between economic growth and stock market. Petros (2012) used FMOLS and ARDL bounds testing approach to determine the relationship between stock market development and economic growth in Zimbabwe from 1991 to 2007. The results indicated that there was a significant positive relationship between stock market development and economic growth. An investigation on the relationship between capital markets and economic growth in Zimbabwe using secondary data from 1990 to 2015 and Granger Casuality test indicated a unidirectional causality running from the stock market to economic growth (Badze \& Nhavira, 2016). Still in Zimbabwe, Maposa \& Muma (2017) using post dollarization data from 2005 to 2013 investigated the short and long run impact of stock market development to economic 
growth based on Johansen cointegration test, VECM causality tests, impulse response functions and variance decompositions. The findings revealed a positive impact of the stock market to economic growth both in the short and long run.

In Botswana, Akinboade (1998) tested the relationship based on the Granger Causality test and using real non-mineral GDP per capital as an economic indicator and ratio of non-bank claims on the private sector to nominal non-mineral GDP and ratio of bank deposit liabilities to nominal non-mineral GDP as financial development indicators over the 1972 - 95 period. The results revealed a bidirectional causality relationship between the financial development and economic growth. Ahmed \& Mmolainyane (2014) carried out a study to determine the effect of capital market development on economic performance in Botswana over the period 1974 2009. The results showed a positive and significant short-term relationship between stock market development and economic growth.

\section{Data Analysis}

\section{DATA ANALYSIS, FINDINGS AND DISCUSSIONS}

This paper, as already discussed seeks to assess the contribution of capital markets on economic growth. In particular, we investigate whether there is a long run relationship between economic growth and stock and bond market in Botswana. The data used for this study consists quarterly GDP and stock and bond index data running for 6 years between the first quarter of 2010 up to the third quarter of 2017. The choice of 2010 as our base was influenced by the fact the bond index data used in this study only start from 2010 . Although the Botswana GDP and equity data transcends over a long period of time dating many years ago we decided to use 2010 as our starting point just for the purpose of data consistency. The GDP data was downloaded from Bank of Botswana Website and stock and bond market data was sourced from Botswana Stock Exchange. The stock market data consists of Domestic Companies index (DCI) whist the bond market data consists of the Botswana Bond Index (BBI). The DCI was chosen instead of the other equity index, Foreign Companies Index (FCI)) because it represent the Botswana's stock market better than the latter. With regards to the bond market we chose the BBI as it is an aggregate index which represents the Botswana bond market as a whole including both the government and corporate bond markets. The table below summarizes the properties of our three data sets.

Table 1: Descriptive Statistics

\begin{tabular}{lrll}
\hline DESCRIPTIVE STATISTIC & BBI & DCI & GDP \\
\hline Mean & 140.054 & 8616.16 & 329311 \\
Median & 142.47 & 8960.24 & 326042 \\
Maximum & 177.61 & 10872.7 & 443935 \\
Minimum & 100.97 & 6829.23 & 196176 \\
Standard Deviation & 24.2763 & 1275.24 & 73701.2 \\
Skewness & -0.1088 & 0.01385 & -0.0176 \\
Kurtosis & 1.70545 & 1.61494 & 1.86481 \\
\hline
\end{tabular}

The descriptive statistics shown in table 1 above indicate that the data does not follow a normal distribution. Statistically, in order for series normally distributed, it should have a skewness value of zero and a kurtosis value of about three in a Gaussian distribution. Therefore, with non-zero skewness values of the $-0.1088,0.01385$ and -0.0176 for BBI, DCI and GDP respectively, this suggest the series is skewed either to the left or to the right and hence does not follow a normal distribution. Further, the kurtosis values of 1.71, 1.61 and 1.86 for 
BBI, DCI and GDP respectively suggest that the distributions have heavier tails and sharper peaks than the normal distribution.

The interrelationship between each of the variables used in our analysis is presented in the table below.

Table 2: Correlation Statistics

\begin{tabular}{llll}
\hline & BBI & DCI & GDP \\
\hline BBI & 1 & 0.85584 & 0.97059 \\
DCI & 0.85584 & 1 & 0.81889 \\
GDP & 0.97059 & 0.81889 & 1 \\
\hline
\end{tabular}

The correlation test shows the strength of the relationship between all the variables used in an investigation. The results of the correlation test in table 2 above shows that there exist a strong positive relationship between GDP and BBI with a value of 0.97 .Furthermore there is also a strong positive relationship between GDP and DCI with a value of 0.82 .

Next we perform unit root test to check on whether the series used is stationary or nonstationary. A stationary data is essential in statistical analysis as it helps reduce the problem of spurious regression. It is therefore important to ensure that the three data series that we employ in this analysis are stationary because the latter is a preliminary condition to carry out the subsequent tests that we employ in this study to test both long and short term relationship between our variables, including Cointergration and Vector Error Correction Model (VECM).

Identifying that a series is not stationary enables us to study where the non-stationarity comes from. A non-stationary series can be stationary in first difference also known as integrated of order 1 I (1). Granger (1986) illustrated that if the non-stationarity is purely due to unit roots, i.e. $\mathrm{x} t \sim I(1)$, then the time series can be made stationary by the linear transformation of differencing, i.e. $\mathrm{xt}-\mathrm{xt}-1=D \mathrm{xt} \sim I(0)$.

We use the commonly applied Augmented Dickey-Fuller test (ADF) to check for stationarity and hence the presence of a unit root in our data series. The results as presented in Table 3 show that the t-statistic for GDP, BBI and DCI at $-8.87,-4.72$ and -6.59 respectively, which are smaller than the critical values at the $1 \%, 5 \%$ and 10\% significance level which means the null hypothesis of a unit root is rejected suggesting that the data is stationary. This was done after falling to reject the null using level data and hence differencing the data once suggesting that our three data sets has first order integration, ie. I (1).

Table 3: Results of the unit root test using Augmented Dickey-Fuller Test (ADF)

\begin{tabular}{ll}
\hline VARIBLE & T-STATISTIC \\
\hline GDP & -8.868 \\
BBI & -4.7151 \\
DCI & -6.5858 \\
\hline
\end{tabular}

Test critical values: $1 \% \quad-3.679322$

$5 \% \quad-2.967767$

$10 \% \quad-2.622989$

After ruling out the presences of a unit root and non-stationarity (after differencing) which could lead to spurious regression we continue to perform regression analysis, cointergration 
and apply VECM in our data series to check for both short and long term relationship between our variables. First we present the results of regression analysis which we discuss below.

\section{Regression Results}

This study used multiple regression under the model of the form $\mathbf{Y}_{t}=\boldsymbol{\beta}_{\mathbf{1}}+\boldsymbol{\beta}_{\mathbf{2}} \mathbf{X}+\boldsymbol{\beta}_{\mathbf{3 t}} \mathbf{z}+\boldsymbol{\mu}$,

where Yt is the dependent variable (GDP), $\beta 2 \mathrm{x}$ is the coefficient of bond index and $\beta 3 \mathrm{z}$ is the coefficient of stock market index and $\beta 1$ being the intercept and $\mu$ being the standard error term. Theoretically it is expected that each parameter to have a positive sign to demonstrate the linear relationship between economic growth, stock market and bond market. Although Beck \& Levine( 1998) indicate that stock markets are good predictors of economic, the results of this study suggest otherwise, and they show instead that, in the case of Botswana stock markets have a negative relationship with economic growth. The regression equation generated from our input data is as follows:

\section{GDP= -84944.92+3148.94BBI-4.98DCI+18283.47}

The regression results show that for every 1 unit increase in stock market index there is a 4.98 unit decrease in GDP. In contrast to the bond market there is a positive relationship between GDP and bond index since a 1 unit increase in bond index leads to a 3148.94 unit increase in GDP.

Table 4: Regression Results on GDP against BBI and DCI

VARIABLE COEFFICIENT STANDARD ERROR T-STATISTIC PROBABILTY VALUE

\begin{tabular}{ccccc}
\hline $\mathbf{C}$ & -84944.92 & 2252.83 & -3.78 & 0.0007 \\
BBI & 3138.94 & 272.61 & 11.51 & 0.00 \\
DCI & -2.51 & 4.98 & -0.5 & 0.619 \\
\hline $\mathbf{R}^{2}=0.942561$ & Adjusted $\mathbf{R}^{2}=0.938458$ & F-Statistic=229.7375 F- Statistic (probability) $=0.000$
\end{tabular}

$\mathbf{R}^{2}=0.942561 \quad$ Adjusted $\mathbf{R}^{2}=0.938458 \quad$ F-Statistic $=229.7375$ F- Statistic (probability) $=0.000$

From Table 4 above the p-value for the bond index (BBI) is 0.000 suggesting that the coefficient for the bond index is strong at 1\% level. However the stock market index (DCI) with a p-value of 0.619 is not significant at both $1 \%$ and $5 \%$ level suggesting that the stock market has no significant effect on GDP. The standard error for the coefficient of the BBI and DCI are 0.39444 and 0.008128 respectively. This tells us how reliable the model is, the lower the better. $\mathrm{R}^{2}$ is the proportion of variability of $\mathrm{Y}$ explained by $\mathrm{X}$ or the covariance. It shows how successful the model is in predicting the $Y$ variable. The closer to 1 the better and in this case it is 0.94 which is very close to 1 and hence it is very successful in predicting GDP. The F-statistic is useful in testing the overall significance of the model it answers the question of whether all the independent variables significantly affect the dependent variable. The $p$-value for the $F$ statistic is 0.000 meaning its less than the $5 \%$ significant level which implies that all the independent variables (BBI and GDP) collectively have a significant effect on the dependent variable (GDP).

\section{Cointegration Test}

The purpose of carrying out a cointegration test is to find out if the variables have a long run relationship or association. For this purpose we applied the Johansen (1988) cointegration test and the results reveals that is a long run relationship between GDP, Botswana bond Index as well as the domestic companies index. Before applying the cointergration test we used Schwarz Information Criterion (SIC) to select the suitable lag length which was chosen as 2 
using Eview software. The results of the tests for the model are presented in table $\mathbf{5}$ and they indicate that using both the trace test and maximum Eigen value statistics reject the null of $r \leq$ 0 against the alternative $r \geq 1,(r)$ being the cointegrating relations at $5 \%$ level of significance with the $p$ values for the trace statistic at $r \leq 1$ being 0.74 and 0.76 for the Max-Eigen statistic at the $5 \%$ significance level, suggesting that there is evidence for the presence of one cointegrating vector in this model. The results of the cointegration test therefore show that the residuals are cointegrated at $5 \%$ critical value and zero level of differencing $I(0)$.This implies the existence of a long run relationship between the variables. Hence GDP can be predicted in the long run using the selected explanatory variables.

Table 5: Johansen Cointegration Test Results

\begin{tabular}{cccccc}
\hline $\begin{array}{c}\text { Hypothesized } \\
\text { No. of CEs }\end{array}$ & Eigen Value & $\begin{array}{c}\text { Trace } \\
\text { statistic }\end{array}$ & $\begin{array}{c}\text { Probability } \\
\text { value }\end{array}$ & $\begin{array}{c}\text { Max- } \\
\text { Eigen } \\
\text { Statistic }\end{array}$ & $\begin{array}{c}\text { Probability } \\
\text { Value }\end{array}$ \\
\hline None & 0.41081 & 20.93564 & 0.0003 & 15.3412 & 0.0002 \\
At most 1 & 153286 & 5.59445 & 0.7428 & 0.7428 & 0.7637 \\
At most 2 & 0.026171 & 0.7690057 & 0.3805 & 0.3805 & 0.3805 \\
\hline \multicolumn{7}{c}{ (GDP, BBI, DCI) VAR lag =2 } & &
\end{tabular}

Having established a long run relationship the study continues with a vector error correction model (VECM) test for short term dependence in our data series.

\section{Vector Error Correction Model (VECM)}

In order to check for short term dependence between GDP and our dependent variables (BBI and DCI) we run the Vector Error correction model. One of the preliminary conditions to use VECM is that the data should be non-stationary at levels but stationary after differencing. The ADF test that we performed earlier suggest that our data series are stationary after differencing it once (i.e the data has first order intergration, $I(1)$ ). The other condition that should be satisfied is that the data should be cointergrated, and after applying Johansen's contergration test we established that indeed there is contegrating relationships between our I(1) variables. Therefore we applied the VECM to establish short run relationship between our variables. VECM is actually a modification to the Vector Autoregressive (VAR) system and it add an error correction term to VAR because the last period deviation from long run equilibrium influences the short run dynamic of the dependent variable.

The VECM test presented in tables 6 and 7 suggest that there is a negative relationship between GDP and the capital markets but the relationship is insignificant. With GDP being the dependent variable it seems that both the bond index and the stock market index influence GDP negatively in the short run since their coefficients are negative with BBI(-1) $=-4.297753$ and $\operatorname{DCI}(1)=-0.009220$.Therefore we reject the notion that capital markets contribute to economic growth in Botswana in the short run. This contradicts studies carried out by Levine and Zervos (1998).Contrariwise these results are also in line with Handa and Khan (2008) who found out that there was no causality between stock market development and economic growth in developing countries. 
Table 6:VECM Results using Short Run equation (Lag order 2)

\begin{tabular}{cccc}
\hline & Coefficient & t-statistic & Probability \\
\hline D(GDP(-1)) & 0.284254 & 1.568912 & 0.1324 \\
D(BBI(-1)) & -4.297753 & -3.041766 & 0.0064 \\
D(DCI(-1)) & -0.00922 & -0.840716 & 0.4104 \\
D(GDP(-2)) & 0.37847 & 2.269004 & 0.0345 \\
D(BBI(-2)) & -0.686096 & -0.504934 & 0.6191 \\
D(DCI(-2)) & -0.021517 & -1.674468 & 0.1096 \\
C & 1133.609 & 2.488006 & 0.0218 \\
\hline
\end{tabular}

Table 7: Wald Test Results

\begin{tabular}{ccc}
\hline Test Statistic & Value & Probability \\
\hline F- statistic & 4.58133 & 0.0087 \\
Chi-square & 18.3235 & 0.0011 \\
\hline
\end{tabular}

\section{CONCLUSIONS AND RECOMMENDATIONS}

\section{Conclusions}

This paper has evaluated the contribution of the capital markets on economic growth using market indices and gross domestic product in Botswana. This is a subject that has not been extensively studied in the context of Botswana but it has received widespread interest all over the world. Most studies have only focused on the stock market or the bond market individually and how they affect economic growth. Therefore this paper studied both of these variables independently in order to deduce their contribution to the growth of the Botswana economy. As it has already been established in earlier chapters the role of the capital markets is fostering capital in the economy through savings mobilization, easing risk management, promoting technological transfer and reducing transaction costs (Schumpeter ,1911) proving its significance to the financial system of a country. With this significance it was only right to establish what their contribution to economic growth was .Therefore the results of the research confirm in part that capital markets do contribute to economic growth in Botswana. The findings show that the bond market has a significant contribution to economic growth than the stock market. From the Johansen, (1988) cointegration test results it is evident that the there is a long run association between GDP and capital markets. This means that in the long run capital markets will contribute to economic growth of Botswana. However, using VECM, the short run association could not be established. In sum, the results of this paper concludes that capital markets do not have a significant contribution to economic growth of Botswana in the short run, however in the long the capital markets have the potential to contribute largely to economic growth of Botswana.

\section{Recommendations}

With further capital markets development the capital markets can be able to contribute significantly to economic growth of Botswana. However most capital markets in emerging economies do not have a highly developed stock market this also holds true to Botswana. Therefore this holds back the capability of the stock market to fully contribute to economic growth. In order to achieve this, capital market development in Botswana should be a priority. It is evident that the banking system contributes more to economic growth as shown by studies conducted by Arestis et.al, (2001) where stock markets were seen to have a causal relationship with economic growth but contributed little to economic growth. Therefore the extensive development of the Botswana Stock Exchange is needed including diversifying product offering and encouraging listing. However it is not easy as most companies are reluctant to list on the BSE because of the extensive listings requirements that come with listing. Therefore the BSE 
should take an initiative to make listing on the stock exchange easier. Furthermore there is still very little knowledge about capital markets by the public only a fraction of the population of Botswana know about the stock market let alone the bond market. Hence more awareness should be raised to the public. Already the BSE has put in place an open market day in which they go to different villages teaching about the securities that are traded in the stock market. With more awareness I believe that this would increase the participants of the stock market and thereby effectively increasing liquidity which is one indicator that shows the development of the capital markets. Innovation and development of new products is also essential for the development of the capital markets in Botswana therefore the BSE should work tirelessly to develop products both in the stock and bond market that would appeal to investors thereby increasing their visibility in the economy. This way the capital markets will be able to significantly contribute more to the economy of Botswana.

\section{References}

Ahmed, A. D., \& Mmolainyane, K. K. (2014). Financial integration, capital market development and economic performance: Empirical evidence from Botswana. Economic Modelling, 42, 1-14

Acquah-Sam, E., \& Salami, K. (2014). Effect of capital market development on economic growth in Ghana. European Scientific Journal, ESJ, 10(7).

Akinboade, O. A. (1998). Financial development and economic growth in Botswana: a test for causality. Savings and Development, 331-348.

African Economic Outlook. (2012).Promoting Youth Employment. Retrieved from https://www.africaneconomicoutlook/sites/default/files/content-pdf/AE02012_EN.pdf

Ali, M. (2011). Impact of Micro and Macroeconomic Variables on Emerging Stock Market Retur:A case of Dhaka Stock Exchange. Interdisciplinary Journal of Research in Business, 08-16.

Arestis, P., Demetriades, P., \& Luintel, K. (2001). Financial Development and Economic Growth :The Role of Stock Markets . Journal of money,credit and Banking, 33(1), 16-41.

Atje, R., \& Jovanovic, B. (1993). Stock Markets and Development. European Economic Review, 37(2) ,632-640.

Ayala, D., Nedeljkovic, M., \& Saborowski, C. (2017). What Slice of the Pie?The Corporate Bond Market Boom in Emerging Economies. Journal of Financial Stability, 30(3),16-35.

Badze, L., \& Nhavira, J. D. G. (2016). Capital markets and economic growth in Zimbabwe. Journal of Strategic Studies: A Journal of the Southern Bureau of Strategic Studies Trust, 7(1), 27-41.

Bank of Botswana. (2017).2016 Annual Report of the Bank of Botswana. Retrieved from http://www.bankofbotswana.bw/index.php/content/2009110614010-annual-report

Beck, T., \& Levine, R. (2002). Stock Markets,Bank and Growth:Panel Evidence. Journal of Banking and Finance, 1(3),423-442.

Bencivenga, V., Smith, B., \& Starr, R. (1995). Trabsactions,Costs,Technoligical Choice and Endogenous Growth. Journal of Economic Theory, 67(1),53-177.

Botswana Stock Exchange. (2017, September 17.Retrieved from www.bse.co.bw/abt_us/role_in_botswana.php

Botswana Stock Exchange. (2015). 2015 Annual Report of the Botswana Stock Exchange. Retrieved from www.bse.co.bw

Brigham, E., \& Houston, J. (2004). Fundamentals of Financial Management. Natorp Boulevard: Thomson South Western.

Bulere, T. (2015). Stock Market Development and Economic Growth in Uganda. Netherlands: Institute of Social Studies.

Carp, L. (2012). Can stock market development boost economic growth? Empirical evidence from emerging markets in Central and Eastern Europe. Procedia Economics and Finance, 3, 438-444.

Cooray, A. (2010). Do stock markets lead to economic growth?. Journal of Policy Modeling, 32(4), 448-460. 
Coşkun, Y., Seven, Ü., Ertuğrul, H. M., \& Ulussever, T. (2017). Capital market and economic growth nexus: Evidence from Turkey. Central Bank Review, 17(1), 19-29.

Cuza, A. I. (2014). The Success of Emerging Capital Markets in Determining Economic Growth. Cross Cultural Management Journal, 16(1), 139-144.

Diamond, D. (1984). Financial Intermediation and Delegated Monitoring . Review of Economic Studies, 51(1) ,393414.

Enekwe, C. I., Eziedo, K. N., \& Agu, C. I. (2016). Effect of Capital Market on Economic Growth in Nigeria. GOUNI Journal of Management and Social Sciences, 4(1), 33-46.

Enisan, A., \& Olufisayo, A. (2009). Stock Market Development and Economic Growth:Evidence from Seven SubSahara African Countries. Journal of Economics and Business, 61(1), 162-171.

Fink, G., Haiss, P., \& Hristoforova, S. (2003). Bond Markets and Economic Growth. Research Institute for European Affairs, Working Paper 49.

Granger,C.W.J. (1986).Developments in the Study of Cointegrated Economic Variables, Oxford Bulletin of Economics and Statistics,48, 213-228

Goldsmith, R. (1969). Financial structure and development. National Bereau of Economic Research, 114-123.

Greenwood, J., \& Jovanovic, B. (1990). Financial Development Growth and the Distribution of Income. Journal of Political Economy, 98(1), 1076-1107.

Handa, J., \& Khan, S. (2008). Financial Development and Economic Growth;A Symbaotic Relationship. Applied Financial Economics, 18(13), 1033-1049.

Harvey, C. (1989). Forecasts of Economic Growth from the Bond and Stock Markets. Financial Analysts Journal, 45(5), 38-45.

Johansen, S. (1988). Statistical Analysis of Cointegrating Vectors. Journal of Economic Dynamics and Control, 12(2),231-254.

Johansen, S., \& Juselias, K. (1992). Testing Structural Hypothesis in a Multivariate Cointegraion Analysis of the PPP and UIP for UK. Journal of Econometrics, 53(1),211-244.

John E. Elliott, (1985) "Schumpeter's Theory of Economic Development and Social Change: Exposition and Assessment", International Journal of Social Economics, Vol. 12 Issue: 6/7, pp.6-33

Kapingura, F., \& Makhetha-Kosi, P. (2014). The Causal Relationship between the Bond Market Development and Economic Growth in Afica:Case Study of South Africa. Mediterranean Journal of Social Sciences, 5(3),126-131.

Kaserer, C., \& Rapp, M. S. (2014). Capital markets and economic growth: long-term trends and policy challenges. The Alternative Investment Managemen $t$ Association Research Report.

Khetsi, Q. S., \& Mongale, I. P. (2015). The impact of capital markets on the economic growth in South Africa. Journal of Governance and Regulation, 4(1-2), 154-163

King, R. G., \& Levine, R. (1993). Finance, entrepreneurship and growth. Journal of Monetary economics, 32(3), 513542.

Koirala, J. (2011). The Effect of Stock Market Development on Economic Growth: An Empirical Analysis of UK.

Levine, R. (2005). Finance and Growth:Theory and Evidence. Handbook of Economic Growth, 1(1) ,865-934.

Levine, R., \& Zervos, S. (1998). Stock Markets,Banks and Economic Growth. America Economic Association, 88(3),537-558.

Maposa, L., \& Muma, F. M. (2017). The Impact of Financial Development on Economic Growth in Zimbabwe: Comparative Analysis of Stock Markets and Commercial Banks. Open Access Library Journal, 4(08), 1.

Marques, L. M., Fuinhas, J. A., \& Marques, A. C. (2013). Does the stock market cause economic growth? Portuguese evidence of economic regime change. Economic Modelling, 32, 316-324.

Ngare, E., Nyamongo, E. M., \& Misati, R. N. (2014). Stock market development and economic growth in Africa. Journal of Economics and Business, 74, 24-39.

Njemcevic, F. (2016, October). Capital Market and Economic Growth in Transition Countries: Evidence from South East Europe. In 8th International Conference of the School of Economics and Business (Vol. 48, p. 146). University of Sarajevo, School of Economics and Business Trg oslobodjenja-Alija Izetbegovic 1, Sarajevo, Bosnia and Herzegovina. 
Nordin, S., \& Nordin, N. (2016). The impact of capital market on economic growth: a Malaysian outlook. International Journal of Economics and Financial Issues, 6(7S), 259-265.

Nuhiu, A., \& Hoti, A. (2011). Effects of capital markets development on economic growth of Western Balkan countries. European Journal of Economics, Finance and Administrative Sciences, 43, 88.

Obiakor, R., \& Okwu, A. (2011). Empirical Analysis of Impact of Capital Market Development on Nigeria's Economic Growth(1981-2008):Case study;Nigerian Stock Exchange. Business and Economic Review, 20(2), 79-96.

Pan, L., \& Mishra, V. (2018). Stock market development and economic growth: Empirical evidence from China. Economic Modelling, 68, 661-673.

Phadke, C. (2015). Study of Capital Markets in Emerging Economies. The Business Management Review, 5(4),1-8.

Pradhan, R. P., Arvin, M. B., Hall, J. H., \& Bahmani, S. (2014). Causal nexus between economic growth, banking sector development, stock market development, and other macroeconomic variables: The case of ASEAN countries. Review of Financial Economics, 23(4), 155-173.

Petros, J. (2012). The effect of the stock exchange on economic growth: a case of the Zimbabwe stock exchange. Research in Business and Economics Journal, 6, 1.

Robinson S. (1972).Theories of Economic Growth and Development: Methodology and Content. Economic Development and Cultural Change 21, no. 1, 54-67.

Schumpter, J. (1911). Theorie der witschaftlichn Entwicklung:transl.1934,The theory of economic development:An inquiry into profits,capital,credit,interest and the business cycle. Cambridge Mass: Harvard University Press.

The World Bank Group. (2017, September 25). Retrieved from http://www.worldbank.org/en/country/botswana/overview

Trading Economics. (2017, September 17). Retrieved from https://tradingeconomics.com/botswana/gdp

Yadirichukwu, E., \& Chigbu, E. E. (2014). The impact of capital market on economic growth: the Nigerian Perspective. International Journal of Development and Sustainability, 3(4), 838-864. 